\title{
Optimization of the Cellulase Free Xylanase Production by Immobilized Bacillus Pumilus
}

\author{
Aditi Kundu and Bijan Majumdar *
}

Crop Production Division, Central Research Institute for Jute \& Allied Fibres, Indian Council of Agricultural Research, Kolkata, India

${ }^{*}$ Corresponding author: Bijan Majumdar, Crop Production Division, Central Research Institute for Jute \& Allied Fibres, Indian Council of Agricultural Research, Kolkata-700120, India. Tel: +91 33 25356124, Fax:+91332535 0415, E-mail: bmajumdar65@gmail.com

Received: 12 Jul. 2016; $\quad$ Revised: 13 Jun.2018; $\quad$ Accepted: 19 Jun. 2018; $\quad$ Published online: 12 Dec. 2018

\begin{abstract}
Background: The extracellular xylanase secreted by microorganisms is a hydrolytic enzyme, which arbitrarily cleaves the $\beta-1,4$ backbone of the polysaccharide xylan; an enzyme used in the food processing, bio-pulping and bio-bleaching. The commercial production of the xylanase is limited because of a higher cost involvement, which can be overcome by the costeffective production of the xylanase through immobilization of the microbial cell by the non-toxic substances.

Objectives: In this work, the optimization of the extra-cellular cellulase free xylanase production by the immobilized cell of the Bacillus pumilus IMAU80221 strain using Ca-alginate beads along with standardization of the various parameters for a higher xylanase production were studied.

Materials and Methods: Following to sterilization, the Na-alginate solution was mixed with the bacterial suspension of the Bacillus pumilus IMAU80221 and was added drop by drop into the $1 \mathrm{M}$ calcium chloride solution for $1 \mathrm{~h}$ for obtaining a uniform sized polymeric bead of the Ca-alginate. For xylanase production, the Ca-alginate beads were then transferred into $100 \mathrm{~mL}$ Erlenmeyer flasks with $20 \mathrm{~mL}$ of the culture medium containing (w/v) $0.02 \% \mathrm{NaCl}_{1} 0.02 \% \mathrm{MgSO}_{4}, 0.04 \%$ $\left(\mathrm{KH}_{4}\right)_{2} \mathrm{PO}_{4}, 0.1 \%$ peptone, and $0.5 \%$ xylan and incubated at $34{ }^{\circ} \mathrm{C}$ in an incubator shaker $(150 \mathrm{rpm})$ for $24 \mathrm{~h}$. The resultant supernatant (crude enzyme) was used for enzyme assay.

Results: The maximum xylanase production by the free cell $\left(1.9 \mathrm{U} \cdot \mathrm{mL}^{-1} \cdot \mathrm{min}^{-1}\right)$ was recorded at $48 \mathrm{~h}$ which was $40.5 \%$ lower than the xylanase production by the immobilized cell $\left(2.67 \mathrm{U} \cdot \mathrm{mL}^{-1} \cdot \mathrm{min}^{-1}\right)$ at the same time. The beads containing the immobilized cells could be reused up to eight fermentation cycles for xylanase production and retained $83.5 \%$ of the productivity at the fourth cycle. The entrapped cells were stable after six months of storage at $4{ }^{\circ} \mathrm{C}$ and retained $68 \%$ of the xylanase productivity.

Conclusion: Cellulase free xylanase production from the immobilized Bacillus pumilus IMAU80221 was optimized. The xylanase production by the immobilized cells of Bacillus pumilus was higher by 40.5 and $132.6 \%$ over the free cells respectively after 48 and $72 \mathrm{~h}$ of the incubation.
\end{abstract}

Keywords: Bacillus pumilus, Cellulase free xylanase, Calcium alginate, Immobilization

\section{Background}

Xylanase, a hydrolytic enzyme, arbitrarily cleaves the $\beta-1,4$ backbone of polysaccharide xylan, is one of the most common renewable polysaccharides of the plant origin after cellulose, accounting 20 to $40 \%$ of the plant dry biomass with a large scope of industrial application. These enzymes are extensively used in the food processing, improvement of digestibility of the animal feed, important processes like bio-pulping, biobleaching in the paper and pulp industries (1), as well as bio-conversion of the lignocelluloses into feed-stocks and fuels (2). Xylanase is also used for coffee extraction,

Copyright (C) 2018 The Author(s); Published by National Institute of Genetic Engineering and Biotechnology. This is an open access article, distributed under the terms of the Creative Commons Attribution-NonCommercial 4.0 International License (http://creativecommons.org/licenses/ by-nc/4.0/) which permits others to copy and redistribute material just in noncommercial usages, provided the original work is properly cited. 
extraction of oils and starch from plant origin, and for clarification of the fruit juice in combination with pectinases and cellulases, degumming and retting of bast fibres like sunnhemp, ramie, and jute $(3,4)$.

High amounts of extracellular xylanases are secreted by several microorganisms including bacteria, actinomycetes, and filamentous fungi. Secretion of xylanase often occurs in association with a low to a higher amount of cellulases production. Most of the xylanases producing strains like Cellulomonas fimi (5), Clostridium stercorarium (6), have a significant cellulase activity. Several xylanase producing strains with the negligible cellulolytic activities like Bacillus SSP-34 (7), Pseudomonas sp. WLUN024 (8), and Bacillus subtilis (9) have also been reported. Three pectinolytic bacterial strains without any cellulolytic activities viz. Bacillus pumilus IMAU80221, Bacillus pumilus GVC11, and Bacillus pumilus SYBC-W isolated from retting water has also been reported (10).

In spite of having advantages of using xylanase enzyme, its commercial exploitation was very limited because of higher cost involvement, which can be resolved by immobilization of the microbial cell. Immobilization of the microbial cells for extracellular xylanase production has several advantages compared to the free cell like a better substrate utilization, longer working life time, ease of separation to facilitate their reuse, protection against high shear damage, favorable microenvironment to the cell, reduction in the possibility of contamination, etc. Despite these advantages, gel degradation, severe mass transfer, low mechanical strength, and large pore size are the limitations associated with the immobilization of the microbial cells. The material and proper technique selection plays a significant role in the immobilization of the microbial cells for commercial production of the extra-cellular xylanase enzyme. The most commonly used and popular method for the microbial cell immobilization is by Ca-alginate beads (11) which has several advantages such as user-friendly lower cost involvement, easier availability, and non-toxic in nature.

The present work describes optimization of the extra-cellular cellulase free xylanase production by the immobilized cells of Bacillus pumilus IMAU80221 strain using Ca-alginate beads along with standardization of the various parameters for a higher xylanase production.

\section{Objectives}

In this work, optimization of the extra-cellular cellulase free xylanase production by the immobilized cells of
Bacillus pumilus IMAU80221 strain using Ca-alginate beads along with standardization of various parameters for higher xylanase production were studied. The outcome of the study will be very useful because of reusability and the long- term storage ability of the entrapped cell.

\section{Materials and Methods}

\subsection{Microorganism and Culture Maintenance}

The working strain, Bacillus pumilus (Accession no. KM091823), a very high xylanase producer was grown on a selective xylan-agar medium, after isolation from the retting water samples of the West Bengal (22.56670 $\mathrm{N}, 88.36670 \mathrm{E}$ ), India (10). The strain was identified as Bacillus pumilus IMAU80221 by $16 \mathrm{SrDNA}$ sequencing (ribotyping) of a 977 bp fragment and was deposited to the MTCC, IMTECH, Chandigarh, India for maintenance. For the preparation of the inoculum, Bacillus pumilus was mixed with $10 \mathrm{~mL}$ basal medium containing (w/v) $0.02 \% \mathrm{NaCl}, 0.02 \% \mathrm{MgSO}_{4}, 0.04 \%$ $\left(\mathrm{KH}_{4}\right)_{2} \mathrm{PO}_{4}, 1 \%$ peptone, and $1 \%$ xylan incubated at 34 ${ }^{\circ} \mathrm{C}$ in a shaker $(150 \mathrm{rpm})$ for $24 \mathrm{~h}$. The microbial cell count in the suspension was $2.0 \times 10^{8}$ cell. $\mathrm{mL}^{-1}$.

\subsection{Whole Cells'Immobilization}

After dissolving sodium alginate (Hi media, Mumbai) in the boiling distilled water it was sterilized in an autoclave at $121{ }^{\circ} \mathrm{C}$ for $15 \mathrm{~min}$. After sterilization, the alginate solution was mixed with the bacterial suspension $\left(2.0 \times 10^{8}\right.$ cell. $\left.\mathrm{mL}^{-1}\right)$ in a conical flask with constant shaking at $250 \mathrm{rpm}$ for $1 \mathrm{~h}$ to get a homogeneous suspension, which was then added drop by drop into the cold $\left(25^{\circ} \mathrm{C}\right)$ sterile $1 \mathrm{M}$ calcium chloride solution for $1 \mathrm{~h}$ using a syringe having nozzle of $1 \mathrm{~mm}$ diameter to obtain a uniform sized polymeric beads of the Caalginate. To remove excess calcium ions, these beads were then washed with distilled water. The whole process of $\mathrm{Ca}$-alginate beads preparation was done aseptically in a laminar airflow chamber. In this study, we prepared calcium alginate beads with four different concentration of the sodium alginate.

\subsection{Fermentation and Enzyme Production}

The Ca-alginate beads were then kept in a $100 \mathrm{~mL}$ Erlenmeyer flasks having $20 \mathrm{~mL}$ of culture medium containing (w/v) $0.02 \% \mathrm{NaCl}, 0.02 \% \mathrm{MgSO}_{4}, 0.04 \%$ $\left(\mathrm{KH}_{4}\right)_{2} \mathrm{PO}_{4}, 0.1 \%$ peptone, $0.5 \%$ xylan incubated at $34^{\circ} \mathrm{C}$ and shaking at $150 \mathrm{rpm}$ in an incubator shaker for $24 \mathrm{~h}$. After cultivation, beads were separated out from the medium, centrifugation of broth culture was carried out at $10,000 \times \mathrm{g}, 4^{\circ} \mathrm{C}$ for 10 minutes, and the resultant supernatant was used as the crude enzyme. 


\subsection{Enzyme Assay}

The xylanase activity was measured by reducing sugar estimation method (12) using 3, 5 dinitro salicylic acid and taking xylose as a standard. In reducing sugar estimation method, the assay mixture $(1 \mathrm{~mL})$ containing an equal volume of the enzyme and $1 \%(\mathrm{w} / \mathrm{v})$ birch- wood xylan (Sigma, U.S.A) was dissolved in $0.1(\mathrm{M})$ phosphate buffer $(\mathrm{pH} 6)$ and incubated at $50{ }^{\circ} \mathrm{C}$ for 10 minutes. The reaction was then stopped by adding $1 \mathrm{~mL}$ of 3,5 dinitro salicylic acid reagents. A blank was run simultaneously that contained all the reagents with inactivated enzymes by heating at $100{ }^{\circ} \mathrm{C}$ for 30 minutes. The contents were placed in a boiling water bath for $10 \mathrm{~min}$ for the color development followed by cooling at room temperature. The absorbance was measured at 540 nm against the blank. The xylanase activity was determined by using a calibration curve of D-xylose (Himedia). One unit of enzyme activity was defined as the amount of enzyme that released 1 mili mole of reducing sugar by hydrolyzing xylan per milliliter per minute under assay conditions.

\subsection{Optimization of the Different Parameters for Enzyme Production}

The flasks containing culture were incubated at four different concentrations of the $\mathrm{Ca}$-alginate beads ( 3 , 5,7 , and $9 \%$ i.e. $3,5,7$, and $9 \mathrm{~g}$ of the sodium alginate was dissolved individually in $100 \mathrm{~mL}$ of water) at 34 ${ }^{\circ} \mathrm{C}$ for $24 \mathrm{~h}$ in order to study the effect of concentration of the Na-alginate on xylanase production. Similarly, the flasks having cultures in optimized media were incubated for different time intervals varying from 24 to $120 \mathrm{~h}$ and then measurement of xylanase activity was done to study the changes in the xylanase production under different cultivation times. To study the effect of agitation on enzyme production, flasks having cultures were incubated at $34{ }^{\circ} \mathrm{C}$ in a shaker incubator at the shaking rate of $50,100,150$, and $220 \mathrm{rpm}$. After each fermentation cycle, beads were collected from the fermentation medium by sterile forceps, properly washed with the sterile water and further transferred into $100 \mathrm{~mL}$ shaking flasks containing $20 \mathrm{~mL}$ of sterile, fresh xylan medium for the next $24 \mathrm{~h}$ incubation in order to continue the repeated cycles of fermentation.

\subsection{Storage of Entrapped Cell}

After enzyme production by immobilized cell, beads were aseptically collected from the medium and washed several times with sterile distilled water for removal of impurities and then stored in sterile water at $4{ }^{\circ} \mathrm{C}$ for future use.

All experiments were replicated thrice and the resultant mean data were presented along with standard errors (SE).

\section{Results}

\subsection{Effect of Different Concentration of Na-alginate} Beads on Xylanase Production

The maximum xylanase production (1.92 U.mL $\left.\mathrm{mL}^{-1}\right)$ was recorded with beads containing with $5 \%$ alginate followed by $7 \%$ sodium alginate concentration (1.64 U.mL $\mathrm{mL}^{-1}$ ) and the minimum concentration was recorded at $9 \%$ alginate concentration $\left(1.53\right.$ U.mL $\left.{ }^{-1}\right)$ (Fig. 1). The xylanase production with $5 \%$ alginate was higher by 17.1 and $25.5 \%$ over the production at $7 \%$ and 9\% alginate concentration. From the study, it is clear that the lower and a higher concentration of alginate recorded comparatively lower xylanase concentration product.

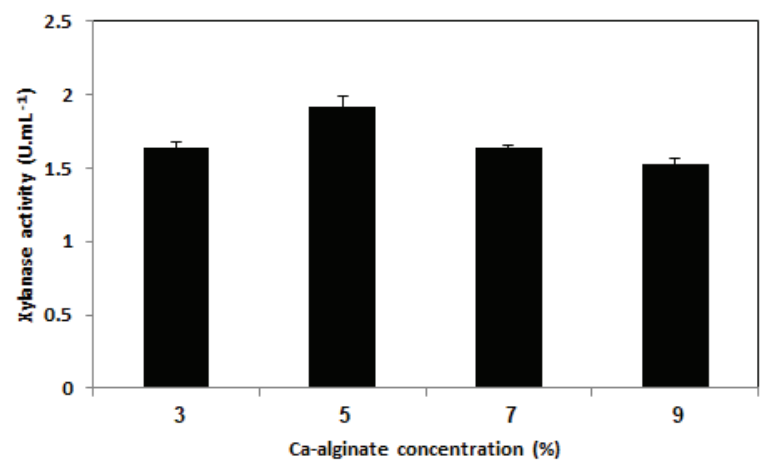

Figure 1. The effect of calcium alginate concentration on xylanase production by immobilized Bacillus pumilus.

\subsection{Effect of Incubation Time on Xylanase Production}

The xylanase production was measured under various incubation time ranging from 24 to $120 \mathrm{~h}$. The maximum xylanase production (1.9 U.mL $\left.\mathrm{mL}^{-1}\right)$ by free cells was recorded at $48 \mathrm{~h}$, while at the same time, the xylanase production by the immobilized cell was 2.67 U.mL ${ }^{1}$, which was $40.5 \%$ higher compared to the xylanase production by the free cells (Fig. 2). The xylanase production by immobilized cells further increased to a maximum level $\left(2.73 \mathrm{U}_{\mathrm{mL}}^{-1}\right)$ at $72 \mathrm{~h}$ and then gradually decreases with cultivation time. Although the production of xylanase by free cell was higher at $24 \mathrm{~h}$ compared to the immobilized cell, however after that at every point of time, the xylanase production by immobilized cells was higher by 40.5 to $132.6 \%$ over the free cells. 


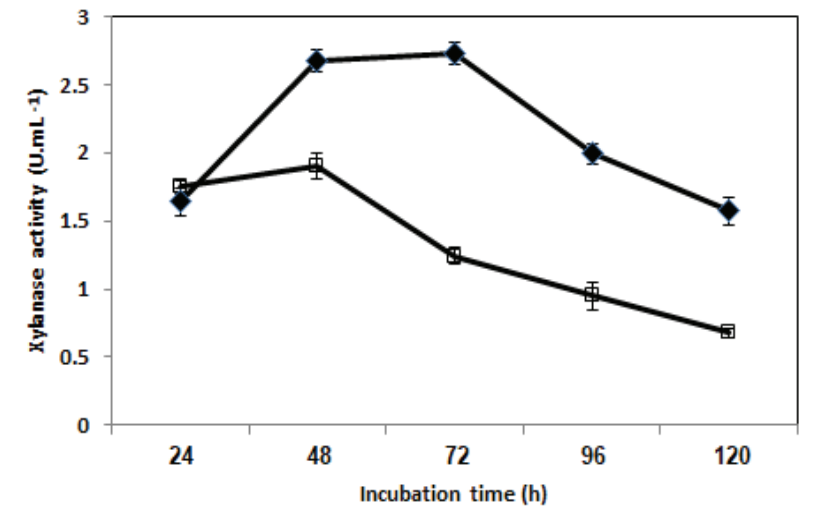

Figure 2. The effect of incubation time on xylanase production by the free and immobilized Bacillus pumilus cells.

\subsection{Effect of Different Agitation Rate on Xylanase Production}

The xylanase production capacity by the immobilized cells was studied under different agitation rate ranging from 50 to $220 \mathrm{rpm}$ in the incubator shaker at $34{ }^{\circ} \mathrm{C}$ for $24 \mathrm{~h}$. It was observed that the optimal agitation rate for the extracellular xylanase production by the strain under study was $100 \mathrm{rpm}$ which recorded the maximum xylanase production of $2.64 \mathrm{U} \cdot \mathrm{mL}^{-1}$. After that, xylanase production was decreased by $28 \%$ with the increase in rpm (Fig. 3).

\subsection{Reuse of the Immobilized Beads}

In repeated batch fermentation, beads containing immobilized cells could be reused sequentially up to eight fermentation cycles of $24 \mathrm{~h}$ with an agitation rate of $150 \mathrm{rpm}$. It was noticed that the highest xylanase production of $1.64 \mathrm{U} . \mathrm{mL}^{-1}$ could be recorded for the entrapped cell at first cycle and it retains $83.5 \%$ of the xylanase production at fourth cycle (Fig. 4). After the fourth cycle, enzyme production reduced gradually,

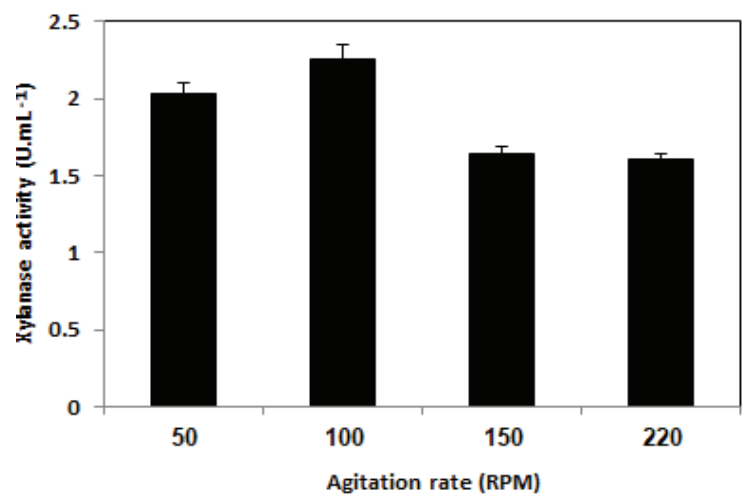

Figure 3. Effect of agitation rate on xylanase production by the immobilized Bacillus pumilus bacterial cells.

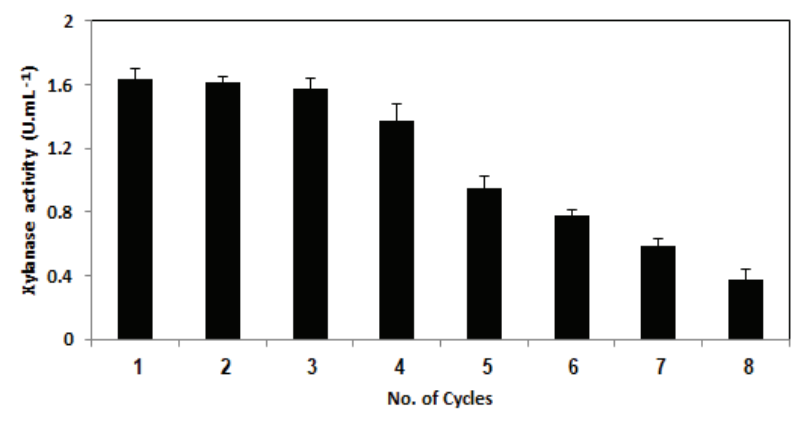

Figure 4. Study of the repeated batch fermentation of the immobilized Bacillus pumilus for xylanase production.

more than half of the production was lost after the fifth cycle that may be due to the abrasion of the support during reuse. Finally, xylanase production by the immobilized cell was retained $23.1 \%$ at the eighth cycle. After each cycle, the beads were in stable condition, easily separated from the medium and no leakage was observed.

\subsection{The Viability of the Stored Immobilized Cell}

The immobilized cells were stored in the sterile distilled water for six months and 12 days at $4{ }^{\circ} \mathrm{C}$. After the storage time, it was noticed that, when the immobilized cells were further grown in the xylan broth medium with a temperature of $30^{\circ} \mathrm{C}$, agitation rate of $150 \mathrm{rpm}$, and incubation time of $24 \mathrm{~h}$, the entrapped cells were viable and stable condition and retained $68 \%$ enzyme production (Fig. 5).

\section{Discussion}

In the present study, out of the four concentrations (3, 5,7 , and $9 \%$ ) of the used alginate, the lower and the higher alginate concentration (3 and $9 \%$ ) recorded lower xylanase productivity compared to 5 and $7 \%$

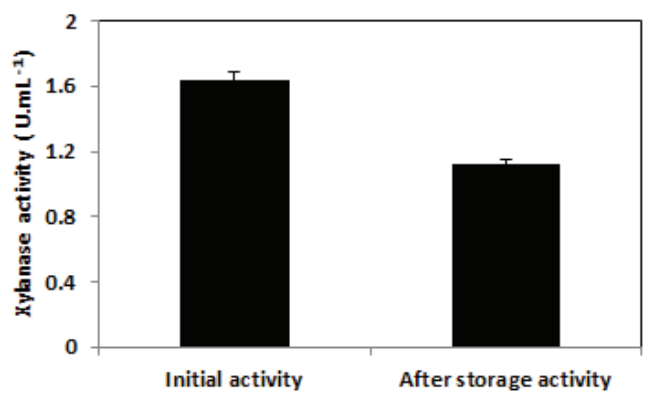

Figure 5. The viability of the stored immobilized Bacillus pumilus cells. 
of the alginate concentration. Preparation of the beads with very low and high alginate concentration have some disadvantage because the low concentration of alginate beads allows quick leakage of the entrapped cells out of the beads (13); on the other hand, the higher alginate concentration checks cells growth and release of enzymes (14). This might have reflected in the higher xylanase production at intermediate concentrations of the alginate ( 5 and $7 \%$ ) compared to the lower xylanase production at lower and higher concentration (3 and 9 $\%)$ of the alginate.

The xylanase production by the immobilized cell of Bacillus pumilus increased with an increase in the incubation time up to $72 \mathrm{~h}$ and then decreased gradually due to a lower supply of nutrients to the microorganism and due to proteolysis creating unfavorable condition for physiological and enzymatic activities of the microbes (15). In case of free cells, the xylanse production was higher at $24 \mathrm{~h}$ compared to the immobilized cell of $B$. pumilus, but with an increase in the incubation time, the xylanse production was lowered by 40.5 to $132.6 \%$ compared to immobilized cells of $B$. pumilus. It could be because of adsorption of bacterial cells on supporting medium and thereby enhancing the residence time of bacterial cells in the medium (16).

The xylanase production by the immobilized cells of Bacilus pumilius was affected by agitation, which was maximum at $100 \mathrm{rpm}$, but decreased with a higher agitation up to $220 \mathrm{rpm}$. The lower xylanase production with a higher agitation rate might be due to the deleterious effect of the higher sheering force; causing the death of bacterial cells and release of proteases which can restrict xylanase production (17).

The beads containing immobilized cells of the Bacillus pumilus could be reused sequentially up to eight fermentation cycle- of $24 \mathrm{~h}$ for xylanase production, although the entrapped cells retained 83.5\% of their xylanase productivity at the $4^{\text {th }}$ cycle. These results are in agreement with the xylanase production by immobilized Bacillus atrophaeus (18).

The immobilized cells of $B$. pumilus were viable after 6 months of storage in sterile distilled water at $4^{\circ} \mathrm{C}$ and retained $68 \%$ xylanse productivity, respectively. This is because of the fact that mild environment of the gel network helped in maintaining a proper viability of immobilized cells in alginate during long-term storage. Similar finding were also reported earlier in which beads were active for 3 months without a decrease in their activity (13). These long-term storage properties are very important for the future applications.

The present study provides valuable information that immobilized strain of Bacillus pumilus in 5\% calcium alginate produced higher cellulose free extracellular xylanase compared to free cells in a very shorter duration of $48 \mathrm{~h}$ and continued to produce higher xylanase up to $72 \mathrm{~h}$. The immobilized Bacillus pumilus can also be reused in eight sequential fermentation cycles for xylanase production although the entrapped cell retained $83.5 \%$ of its production at the $4^{\text {th }}$ cycle. Furthermore, the entrapped cells retained $68 \%$ of xylanase production after six months of storage at $4{ }^{\circ} \mathrm{C}$. Hence, the strain under study has a tremendous scope of the industrial application for extracellular xylanase production without any cellulase activity.

\section{References}

1. Bajpai P. Application of enzymes in the pulp and paper industry. Biotechnol prog. 1999;15 (2):147-157. doi: 10.1021/bp990013k

2. Rifaat HM, Nagieb ZA, Ahmed YM. Production of xylanases by Streptomyces species and their bleaching effect on rice straw pulp. App Ecol Environ Res. 2005;4 (1):151-160. doi: 10.15666/ aeer/0401_151160

3. Kapoor $\bar{M}$, Beg QK, Bhushan B, Singh K, Dadhich KS, Hoondal GS. Application of an alkaline and thermostable polygalacturonase from Bacillus sp. MG-cp-2 in degumming of ramie (Boehmeria nivea) and sunn hemp (Crotalaria juncea) bast fibre. Process Biochem. 2001;36(8-9):803-807. doi: 10.1016/s0032-9592 (00)00282-x

4. Ahmed Z, Akhter F. Jute retting: an overview. J Biol Sci. 2001;1(7):685-688. doi: 10.3923/jbs.2001.685.688

5. Millwardsadler SJ, Poole DM, Henrissat B, Hazlewood, GP, Clarke JH, Gilbert HJ. Evidence for a general role for highaffinity non-catalytic cellulose binding domains in microbial plant cell wall hydrolases. Mol Microbiol.1994;11(2):375-382. doi: 10.1111/j.1365-2958.1994.tb00317.x

6. Sakka K, Kojima Y, Kondo T, Karita S, Ohmiya K, Shimada K. Nucleotide sequence of the Clostridium stercorarium xynA gene encoding xylanase A: Identification of catalytic and cellulose binding domains. Biosci Biotechnol Biochem. 1993;57(2):273277. doi: $10.1271 / \mathrm{bbb} .57 .273$

7. Subramaniyan S, Prema P. Cellulase free xylanases from Bacillus and other microorganisms. FEMS Microbiol Lett.2000;183(1):1-7. doi: 10.1111/j.1574-6968.2000.tb 08925.x

8. Zheng-Hong X, Yun-Ling B, Xia X, Jing-Song S, WenYi T.Production of alkali tolerant cellulose free xylanse by Pseudomonas species WLUN024 with wheat bran as the main substrate. World J Microbio Biotechnol. 2005;21(4):575-581. doi: 10.1007/s11274-004-3491-7

9. Sá-Pereira P, Mesquita A, Duarte JC, Aires Barros MR, CostaFerreira M. Rapid production of thermostable cellulase-free xylanase by a strain of Bacillus subtilis and its properties. Enz Microb Technol. 2002;30(7):924-933. doi: 10.1016/s01410229(02)00034-0

10. Das S, Majumdar B, Saha AR. Biodegradation of plant pectin and hemicelluloses with three novel Bacillus pumilus strains and their combined application for quality jute fibre production. Agric Res. 2015;4(4):354-364. doi: 10.1007/s40003-015-01880

11. Kar S, Mandal A. Production of xylanase by immobilized 
Trichoderma reesei SAF3 in Ca-alginate beads. J Ind Microbio Biotechnol. 2008; 35(4):245-249. doi: 10.1007/s10295-0070292-7

12. Miller GL. Use of dinitrosalicyclic acid reagent for determination of reducing sugar. Anal Chem. 1959;31(3):426428. doi: 10.1021/ac60147a030

13. Dey K, Roy P. Degradation of chloroform by immobilized cells of Bacillus sp. in calcium alginate beads. Biotechnol Lett. 2011;33(6):1101-1105. doi: 10.1007/s10529-011-0553-4

14. Martinsen A, Storro I, Skjark-Braek G. Alginate as immobilization material: III. Diffusional properties. Biotechnol Bioeng. 1992;39(2):186-194. doi: 10.1002/bit.260390210

15. Pathania A, Sharma N, Verma SK. Optimization of cellulasefree xylanase produced by a potential thermoalkalophilic Paenibacillus sp. N1 isolated from hot springs of northern
Himalayas in India. J Microbiol Biotechnol Food Sci. 2012;2:124.

16. Gupta U and Kar R. Optimization and scale up of cellulase free endo xylanase production by solid state fermentation on corn cob and by immobilized cells of a thermotolerant bacterial isolate. Jord. J Bio Sci. 2008;1(3):129-134.

17. Fang HY, Chang SM, Hsieh MC, Fang TJ. Production, optimization growth conditions and properties of the xylanase from Aspergillus carneus M34. J Mol Cat B: Enz. 2007;49(14):36-42. doi: 10.1016/j.molcatb.2007.08.002

18. Kumar D, Kumar A, Guleria A, Kumari A. Isolation, immobilization and characterization of xylanase from a new isolate Bacillus Atrophaeus E8. Int J Sci Res. 2014;3(2):33-36. doi: $10.15373 / 22778179$ 